\title{
BLM Gene Mutation
}

National Cancer Institute

\section{Source}

National Cancer Institute. BLM Gene Mutation. NCI Thesaurus. Code C43287.

A change in the nucleotide sequence of the BLM gene. 